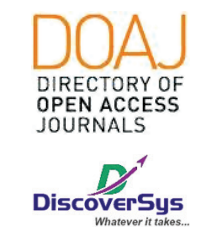

Published by DiscoverSys

\section{Insiden kegemukan pada masyarakat vegetarian di asrama Sri Sri Radha Vrndavan Candra Singaraja}

\author{
Made Naradi Kawiyatna, ${ }^{1 *}$ GN. Indraguna, ${ }^{2}$ Putu Cintya Denny Yuliatni ${ }^{2}$
}

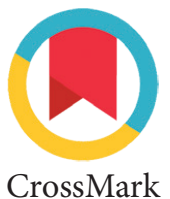

CrossMark

\section{ABSTRACT}

Background: Obesity is one of the health and nutrition problems of the world community, both in developed countries and in developing countries. One effort to solve obesity is being a vegetarian. Vegetarian diet is a diet that only requires vegetable products with or without milk and eggs. This study aims to study the event of obesity in the vegetarian community in the dormitory of Sri Sri Radravanavan Chandra Singaraja.

Methods: This type of descriptive research is carried out by using a retrospective approach. Data collection starting from events that have occurred or are ongoing to do a description of general characteristics and specific variables of the study to answer the research objectives. Variables that have been recorded will be determined by the prevalence of hypertension and overweight. The subjects of the study were hypertensive patients in middleaged with overweight based on data obtained from East Denpasar Puskesmas I. Sampling was done using a random sampling method. the type of research is descriptive study, that means this research only makes a description of the data that has been obtained by using a questionnaire on vegetarians in the dormitory of Radha Vrindavan Candra Singaraja. Data retrieval was taken by the Total Sampling method. Distribution of researcsh variables were BMI, Percent fat and Hip Waist Circumference. 30 samples that meet the inclusion criteria were included in this study.

Results: body mass index variables show that in Male as many as 12 samples (80\%) were classified as healthy and had an average body mass index (SB) of $22.9(2.13) \mathrm{kg} / \mathrm{m} 2$. In the variable body mass index, 14 of female samples (93.3\%) were classified as healthy and had a mean body mass index (SB) of $23.7(1.63) \mathrm{kg} / \mathrm{m} 2$. In Percent Body Fat variables, male shows as many as 4 samples (26.7\%) are included in the category of slightly overlap with an average Percent Body Fat (SB) of 15.6 (4.96\%). In Percent Body Fat variables, females as many as 11 samples (73.3\%) were optimal, with an average Percent Body Fat (SB) of 17.4 (3.24\%). In the Hip Waist Ratio variable male as many as 9 samples (60\%) were at risk of replacing obesity, with an average Hip Waist Ratio (SB) of $0.9(0.03 \%)$. In the female Hip Waist Ratio variable, 12 samples $(80 \%)$ were at risk of obtaining mercy with an average Hip Waist Ratio (SB) of 0.87 (0.02\%). Conclusions: Based on body mass index, in the male sample it was found that 20\% were overweight, while women were only $6.7 \%$. Based on Percent Body Fat, the incidence of obesity was only found in male sex $(20 \%), 13.3 \%$ of women included in the slightly overfat category. Based on the Hip Waist Ratio, $80 \%$ of women are at risk of obesity, while men are $60 \%$.

Keywords: event, obesity, vegetarian

Cite This Article: Kawiyatna, M.N., Indraguna, G.N., Yuliatni, P.C.D. 2019. Insiden kegemukan pada masyarakat vegetarian di asrama Sri Sri Radha Vrndavan Candra Singaraja. Intisari Sains Medis 10(3): 825-829. D0I: 10.15562/ism.v10i3.491

\title{
ABSTRAK
}

Latar Belakang: Kegemukan merupakan salah satu masalah kesehatan dan gizi masyarakat dunia, baik di negara maju maupun di negara berkembang. Salah satu upaya mengatasi kegemukan adalah dengan mengatur pola makan vegetarian Vegetarian adalah pola makan yang hanya mengkonsumsi produk nabati dengan atau tanpa susu dan telur. Penelitian ini bertujuan untuk mengetahui kejadian kegemukan pada masyarakat vegetarian di asrama sri sri radha vrndavan candra singaraja.

Metode: Jenis penelitian ini deskriptif yaitu rancangan penelitian yang hanya melakukan deskripsi mengenai data yang telah diperoleh yaitu dengan menggunakan kuisioner pada masyarakar vegetarian di asrama ari ari radha vrndavan candra singaraja. Pengambilan data di ambil dengan metode Total Sampling. Distribusi variable penelitian yaitu IMT, Persen lemak dan Lingkar Pinggang Pinggul. 30 sampel yang termasuk kriteria inklusi diikutsertakan dalam dalam penelitian ini.

Hasil: laki-laki sebanyak 12 sample (80\%) tergolong healty dan memiliki rata-rata Indeks Masa Tubuh (IMT) (SB) $22,9(2,13) \mathrm{kg} / \mathrm{m}^{2}$.
IMT perempuan 14 sample $(93,3 \%)$ tergolong healty dan memiliki rata-rata IMT (SB) $23,7(1,63) \mathrm{kg} / \mathrm{m}^{2}$. PLT laki-laki sebanyak 4 sampel $(26,7 \%)$ termasuk dalam kategori slighty overfat dengan ratarata PLT (SB) 15,6 (4,96\%). Persen Lemak Tubuh (PLT) perempuan sebanyak 11 sampel $(73,3 \%)$ tergolong optimal, dengan rata-rata PLT (SB) 17,4 (3,24\%). RLPP laki-laki sebanyak 9 sampel (60\%) beresiko mengalami kegemukan, dengan rata-rata Rasio Lingkar Pinggang Pinggul (RLPP) (SB) 0,9 (0,03\%). RLPP perempuan yaitu 12 sampel (80\%) beresiko mengalami kegemukan dengan rata-rata RLPP (SB) $0,87(0,02 \%)$.

Simpulan: Berdasarkan variabel IMT, pada sampel laki - laki ditemukan 20\% yang mengalami overweight, sedangkan perempuan hanya $6,7 \%$. Berdasarkan variabel PLT, kejadian kegemukan hanya ditemukan pada jenis kelamin laki - laki (20\%), 13,3\% perempuan termasuk dalam kategori slightly overfat. Berdasarkan variabel RLPP, $80 \%$ perempuan beresiko mengalami kegemukan, sedangkan laki laki $60 \%$.
Disetujui: 24-11-2019

Diterbitkan: 01-12-2019 
Kata kunci: kejadian, kegemukan, vegetarian,

Cite Pasal Ini: Kawiyatna, M.N., Indraguna, G.N., Yuliatni, P.C.D. 2019. Insiden kegemukan pada masyarakat vegetarian di asrama Sri Sri Radha Vrndavan Candra Singaraja. Intisari Sains Medis 10(3): 825-829. D0I: 10.15562/ism.v10i3.491

\section{PENDAHULUAN}

Kegemukan merupakan salah satu masalah kesehatan dan gizi masyarakat dunia, baik di negara maju maupun di negara berkembang. Menurut Ziegler dan Filler (1996), kegemukan pada dasarnya merupakan suatu kondisi ketidak seimbangan gizi antara zat gizi yang disimpan dalam bentuk lemak tubuh dengan zat gizi yang digunakan untuk menghasilkan energi dan metabolisme tubuh. Selain konsumsi zat gizi, kegemukan juga berkaitan dengan pengeluaran energi tubuh yang dapat dipengaruhi oleh kondisi genetik seseorang, jenis kelamin, umur, obat-obatan, iklim, tempat tinggal, dan stres. Kondisi ini dapat dialami oleh setiap golongan, baik laki-laki maupun perempuan. Gaya hidup masyarakat saat ini lebih memilih mengkonsumsi fast food serta melewatkan sarapan dan cenderung memilih sedentary life style. Penerapan gaya hidup masyarakat saat ini berisiko mengalami kegemukan yang disebabkan oleh beberapa faktor yang kompleks meliputi faktor genetik dan lingkungan. ${ }^{1}$ Menurut Kopelman (2002), yang termasuk faktor lingkungan seperti konsumsi pangan, sosial-budaya, aktivitas fisik atau olahraga, dan metabolik, adapun perkembangan faktor lingkungan lain, seperti sosial-ekonomi dan teknologi yang berperan penting dalam menggeser gaya hidup yang semula sehat menjadi tidak sehat, yang dapat memicu kejadian kegemukan. ${ }^{2}$

Hasil review yang dilakukan Low et al. (2009) menunjukkan prevalensi overweight di negara maju dan negara berkembang mengalami peningkatan. Pada tahun 2008, diperkirakan 1,46 miliar orang dewasa di seluruh dunia mengalami kegemukan (body-mass index [BMI] $>25 \mathrm{~kg} / \mathrm{m}^{2}$ ). ${ }^{3}$ Hasil Riskesdas 2010 menunjukkan bahwa $21.7 \%$ orang dewasa Indonesia mengalami kegemukan (termasuk obesitas), dan perempuan memiliki prevalensi yang lebih tinggi (26.9\%) dibandingkan laki-laki $(16.3 \%) .{ }^{4}$ Kegemukan dapat meningkatkan risiko penyakit tidak menular seperti diabetes sebanyak 4.5 kali, hipertensi 2.5 kali, dan penyakit jantung koroner sebesar $32 \%{ }^{5}$

Salah satu upaya mengatasi kegemukan adalah dengan mengatur pola makan vegetarian. ${ }^{6}$ Vegetarian adalah pola makan yang hanya mengkonsumsi produk nabati dengan atau tanpa susu dan telur, tetapi tidak mengkonsumsi sumber hewani namun masih ada beberapa yang mengkonsumsi ikan. Pengertian ini berkembang menjadi berbagai jenis vegetarian, seperti vegan, lacto vegetarian, vegetarian ovo, vegetarian lacto-ovo, pseudo vegetarian, pollo-vegetarian, pesco vegetarian, semi vegetarian atau flexitarian, frutarian. ${ }^{7}$ Statistik World Health Organization (WHO), secara konsisten menunjukkan bahwa populasi yang mengonsumsi daging dan protein hewani lebih tinggi beresiko memiliki harapan hidup yang lebih rendah dibandingkan orang yang mengonsumsi jumlah protein nabati yang lebih tinggi, yaitu mempunyai harapan hidup rata-rata 90 sampai 100 tahun. ${ }^{8}$ Keuntungan yang didapat dari pola makan vegetarian dikaitkan dengan tingginya kandungan serat, asam folat, vitamin C, kalium, magnesium, zat fitokimia, lemak tak jenuh, dan rendahnya kandungan lemak jenuh serta kolesterol. $^{9}$

Asram Sri Sri Radha Vrndavan Candra yang terletak di daerah Banyuning Singaraja Bali merupakan salah satu kelompok vegetarian yang ada di Bali. Kelompok vegetarian yang berada di asram tersebut sebagian besar menganut lacto vegetarian yang merupakan vegetarian yang mengkonsumsi bahan pangan nabati, dan tidak mengkonsumsi daging ternak, daging unggas, ikan dan telur. Kelompok lacto vegetarian masih diperbolehkan mengkonsumsi susu serta hasil olahannya seperti keju dan yoghurt. Kondisi lingkungan Asram Sri Sri Radha Vrndavan Candra terdapat beragam masyarakat dengan berbagai jenis vegetarian. Salah satu alasan masyarakat memilih menjadi vegetarian pada Asram Sri Sri Radha Vrndavan Candra yaitu untuk menjaga kesehatan, spiritual dan cinta sesama makhluk. Pola makan vegetarian diketahui memiliki berbagai manfaat bagi kesehatan, seperti kadar kolesterol darah yang lebih rendah, risiko penyakit jantung yang lebih kecil, tekanan darah lebih rendah, dan diabetes tipe 2 yang lebih kecil dibandingkan non-vegetarian. ${ }^{10}$ Meskipun telah menjalankan diet vegetarian tetap beresiko mengalami ketidak seimbangan komposisi nutrient, dimana dikhawatirkan proteinya rendah, karena protein pada nabati mengandung bioavelibilitas yang lebih rendah dibandingkan dengan protein pada hewani. Menu tidak seimbang bila dikonsumsi dalam jumblah yang besar akan beresiko mengalami kegemukan.

\section{METODE}

Penelitian ini merupakan penelitian deskriptif dengan desain cross-sectional mengenai kejadian kegemukan pada masyarakat vegetarian di asrama sri sri radha vrndavan candra singaraja 
dilaksanakan pada bulan Desember 2018 setelah peneliti mendapat perizinan oleh komisi etik Fakultas Kedokteran Universitas Udayana/Rumah sakit umum Pusat Sanglah untuk melakukan penelitian.

Sampel penelitian diambil dengan menggunakan metode total sampling. Pada penelitian yang telah dilakukan peneliti memperoleh total sebanyak 30 sampel yang sudah memenuhi kriteria inklusi dan eksklusi. Kriteria inklusi pada penelitian ini adalah anggota vegetarian dari asrama sri sri radha vrndavan candra singaraja yang berusia lebih dari 19 tahun dan sudah menjalani vegetarian lebih dari 2 tahun. Sedangkan kriteria eksklusi pada penelitian ini adalah anggota asrama yang berusia kurang dari 19 tahun dan belum menjalani vegetarian selama 2 tahun di asrama sri sri radha vrndavan candra singaraja.

Pengambilan data yang telah dilakukan menggunakan data primer melalui pengambilan data dengan cara menyebarkan kuisioner. Data yang telah diperoleh disajikan secara deskriptif.

\section{Tabel 1 Karakteristik Sampel Penelitian}

\begin{tabular}{lcc}
\hline Variabel & Frekuensi & Persen (\%) \\
\hline Jenis Kelamin & 15 & 50 \\
Laki - laki & 15 & 50 \\
Perempuan & & \\
Umur & 7 & 23,3 \\
$20-30$ & 12 & 40 \\
$31-40$ & 9 & 30 \\
$41-50$ & 2 & 6,6 \\
$>50$ & 30 & 100 \\
Total & &
\end{tabular}

Tabel 2 Distribusi Frekuensi Kategori IMT, \% Lemak, dan RLPP

\begin{tabular}{lccccc}
\hline & \multicolumn{2}{c}{ Laki - Laki } & & \multicolumn{2}{c}{ Perempuan } \\
\cline { 2 - 3 } \cline { 5 - 6 } Variabel & F & \% & & F & $\%$ \\
\hline IMT & 12 & 80 & & 14 & 93,3 \\
$\quad$ Normal & 3 & 20 & & 1 & 6,7 \\
$\quad$ Overweight & & & & \\
\% Lemak & & & & \\
$\quad$ Lean & 8 & 53,3 & & 11 & 73,3 \\
$\quad$ Optimal & 4 & 26,7 & & 13,3 \\
$\quad$ Slightly Overfat & 3 & 20 & & \\
$\quad$ Fat & & & & \\
RLPP & 9 & 60 & & 12 & 80 \\
$\quad$ Beresiko & 6 & 40 & 3 & 20 \\
$\quad$ Tidak Beresiko & 15 & 100 & 15 & 100 \\
Total & & & &
\end{tabular}

Kemudian, dilakukan perhitungan hasil pengambilan data dalam bentuk tabel dan narasi.

\section{HASIL}

Karakteristik dasar sampel penelitian dapat dilihat pada tabel 1. Dari 30 data yang diperoleh, gambaran umum berdasarkan jenis kelamin responden yang terdapat dalam tabel 2 yaitu jumlah anggota asrama laki - laki sebanyak 15 sample (100\%), dimana 12 sample (80\%) tergolong healty dan 3 sampel (20\%) mengalami overweight. Berdasarkan tabel 5.1.3 variable IMT pada sampel laki-laki memiliki rata-rata IMT (SB) $22,9(2,13) \mathrm{kg} / \mathrm{m}^{2}$. Sedangkan anggota asrama perempuan sebanyak 15 sample (100\%), dimana 14 sample $(93,3 \%)$ tergolong healty dan 1 sample (6,7\%) mengalami overweight. Berdasarkan tabel 5.1.3 variabel IMT pada sample perempuan memiliki rata-rata IMT (SB) $23,7(1,63) \mathrm{kg} / \mathrm{m}^{2}$.

Berdasarkan tabel 2 pada variabel PLT dari anggota laki-laki di asrama terdapat 8 sampel $(53,3 \%)$ dapat dikategorikan optimal, 4 sampel $(26,7 \%)$ termasuk dalam kategori slighty overfat, sedangkan 3 sampel (20\%) termasuk dalam kategori fat. Pada variabel PLT dari anggota laki-laki memperoleh rata-rata PLT (SB) 15,6 (4,96\%). Sedangkan pada variabel PLT dari anggota perempuan di asrama diantaranya terdapat 2 sampel $(13,3 \%)$ tergolong lean, 11 sampel (73,3\%) tergolong optimal, dan 2 sampel $(13,3 \%)$ termasuk dalam kategori slightly overfat. Variabel PLT dari anggota perempuuan memperoleh rata-rata PLT (SB) $17,4(3,24 \%)$.

Pada variabel RLPP anggota asrama laki-laki yang tertera pada tabel 5.1.2 bahwa terdapat 9 sampel (60\%) beresiko mengalami kegemukan dan 6 sampel (40\%) tidak beresiko mengalami kegemukan. Rata-rata RLPP anggota asrama lakilaki adalah RLPP (SB) 0,9 (0,03\%). Sedangkan variabel RLPP anggota asrama perempuan yaitu 12 sampel (80\%) beresiko mengalami kegemukan dan 3 sampel (20\%) tidak beresiko mengalami kegemukan. Variabel RLPP dari anggota asrama perempuan memperoleh rata-rata RLPP (SB) $0,87(0,02 \%)$ (Tabel 3).

\section{DISKUSI}

Pada penelitian ini, peneliti ingin mengetahui prevalensi hipertensi pada orang dewasa menengah dengan overweight. Sampel yang digunakan sebanyak 61 orang, dengan usia $40-60$ tahun. Data dikumpulkan menggunakan pemeriksaan tekanan darah dan penentuan status berat badan dengan $B M I$ chart. Hasil dari penelitian didapatkan bahwa jumlah responden wanita berjumlah 33 orang dan 
Tabel 3 Rata - rata IMT, \% Lemak, RLPP

\begin{tabular}{lccccc}
\hline & \multicolumn{2}{c}{ Laki - Laki } & & \multicolumn{2}{c}{ Perempuan } \\
\cline { 2 - 3 } \cline { 5 - 6 } Variabel & Rata- rata & SD & & Rata - rata & SD \\
\hline IMT & 22,9 & 2,13 & & 23,7 & 1,63 \\
PLT & 15,6 & 4,96 & & 17,4 & 3,24 \\
RLPP & 0,93 & 0,03 & & 0,87 & 0,02 \\
\hline
\end{tabular}

responden pria berjumlah 28 orang, dengan jumlah responden wanita dengan hipertensi sebanyak 18 orang $(54,5 \%)$, sedangkan pada pria dengan hipertensi memiliki didapatkan sebanyak 15 orang $(53,6 \%)$. Hal tersebut menunjukkan bahwa jumlah responden wanita hipertensi dengan overweight lebih tinggi dibandingkan responden pria.

Berdasarkan IMT dari sampel penelitian, distribusi IMT pada laki - laki paling banyak pada kategori Healty/Normal dengan jumlah sampel $12(80 \%)$, dimana didapatkan rerata IMT (SB) $22,9(2,13) \mathrm{kg} / \mathrm{m}^{2}$. pada perempuan paling banyak pada kategori Healty/Normal dengan jumlah sampel 14 (93.3\%) dimana didapatkan IMT (rentang) 23,7 $(20,9: 28,5) \mathrm{kg} / \mathrm{m}^{2}$. Hal ini sejalan dengan penelitian yang dilakukan oleh Prastiwi dimana dalam penelitiannya pada vegetarian didapatkan jumlah IMT paling banyak yaitu dalam kategori Healty/Normal. Hal ini dikarenakan pola makan vegetarian tinggi serat dan rendah asupan lemak. ${ }^{11}$

Berdasarkan PLT dari sampel penelitian, distribusi PLT pada laki - laki paling banyak pada kategori Optimal/Normal dengan jumlah sampel $8(53,3 \%)$ dimana didapatkan rerata PLT (SB) 15,6 (4,96)\%. Pada perempuan paling banyak pada kategori Optimal/Normal dengan jumlah $11(73,3 \%)$ dimana didapatkan PLT (SB) $17,4(3,24) \%$. Hali ini sejalan dengan penelitian yang dilakukan oleh Septian dimana dalam penelitiannya didapatkan PLT pada vegetarian terbanyak pada kategori Optimal/Normal. ${ }^{12} \mathrm{Hal}$ ini dikarenakan pada vegetarian lebih banyak menkonsumsi serat, sedikit asam lemak jenuh dan rendah kalori sehingga akumulasi lemak tubuh sedikit. ${ }^{13}$

Berdasarkan RLPP dari sampel penelitian, distribusi RLPP pada laki - laki paling banyak pada kategori beresiko kegemukan dengan jumah sampel $9(60 \%)$ dimana didapatkan rerata RLPP (SB) $0,9(0,03)$, pada perempuan paling banyak pada kategori beresiko kegemukan dengan jumlah sampel 12 (80\%) dimana didapatkan RLPP (SB) $0,87(0,02 \%)$. Hal ini sejalan dengan penelitian yang dilakukan oleh Nunung dimana didapatkan RLPP Beresiko kegemukan dengan jumlah sampel $56(93,3 \%),{ }^{14}$ didukung dengan penelitian yang dilakukan oleh Ernitasari dimana dalam penelitiannya didapatkan RLPP pada vegetarian yang beressiko kegemukan sebanyak 12,2\% dialami oleh laki - laki dan $55,6 \%$ dialami oleh perempuan. ${ }^{15}$

\section{SIMPULAN}

Berdasarkan jenis kelamin dari sampel penelitian, dapat diketahui bahwa 15 sampel berjenis kelamin laki-laki dan 15 sampel berjenis kelamin perempuan dengan jumlah keseluruhan 30 sampel yang ikut berpartisipasi dalam penelitian ini. Berdasarkan variabel IMT, pada sampel laki laki ditemukan $20 \%$ yang mengalami overweight, sedangkan perempuan hanya 6,7\%. Berdasarkan variabel PLT, kejadian kegemukan hanya ditemukan pada jenis kelamin laki - laki (20\%), 13,3\% perempuan termasuk dalam kategori slightly overfat. Berdasarkan variabel RLPP, $80 \%$ perempuan beresiko mengalami kegemukan, sedangkan laki laki $60 \%$.

\section{KONFLIK KEPENTINGAN}

Penulis menyatakan tidak terdapat suatu konflik kepentingan terhadap publikasi dari artikel ini.

\section{PENDANAAN}

Penelitian ini tidak mendapatkan suatu pendanaan yang diberikan oleh pemerintah ataupun lembaga swasta lainnya.

\section{KONTRIBUSI PENULIS}

Konsep penelitian: Made Naradi Kawiyatna, GN. Indraguna, Putu Cintya Denny Yuliatni. Pengumpulan data, input data dan pengolahan data: Made Naradi Kawiyatna. Penyusunan naskah Penelitian: Made Naradi Kawiyatna.

\section{ETIKA DALAM PENELITIAN}

Penelitian ini telah disetujui oleh Komite Etik Fakultas Kedokteran Universitas Udayana.

\section{DAFTAR PUSTAKA}

1. Ziegler EE., dan Filler LJ. Present Knowledge in Nutrition. Washington DC: ILSI Press. 1996.

2. Kopelman PG et al. New thoughts on managing obesity. Gut 004. 2002.; 53:1044-1053. [dikutip: 27 Juli 2009]. Tersedia dari: http://gut.bmj.com/cgi.

3. Low et al. Faktor Resiko Overweight dan Obese Pada orang Dewasa di Indonesia. 2009.

4. Badan Penelitian dan Pengembangan Kesehatan (Balitbangkes). Riset Kesehatan Dasar (Riskesdas) 2010. Jakarta: Kementrian Kesehatan Republik Indonesia. 2010.

5. Mendez MA., Cooper RS., Luke A., Wilks R., Bennett F., Forrester T. Higher income is more strongly associated with obesity than with obesity-related metabolic disorders in Jamaican adults. International Journal of Obesity, 2004. $28,543-550$. 
6. Rahayu. Pengetahuan tentang vegetarian dan pola makan Pengunjung di restoran loving hut jalan Demangan baru no. 16 yogyakarta. 2017.

7. International Vegetarian Union. IVU News, Volume 7, Cheshire, UK. 2001.

8. World Health Organitation. Obesity and Overweight. 2011.

9. Craig WJ. Health Effects of Vegan Diets, Am J ClinNutr. 2009 89: 1627S-33S

10. American Dietetic Association. Position of The American Dietetic Association Vegetarian Diet. Journal of The American Dietetic Association (ADA). 2009. 109:1267-1268

11. Prastiwi. Body Image Berhubungan Dengan Indeks Massa Tubuh, Tapi Tidak Dengan Waist to Hip Ratio Pada Vegetarian Putri di Surabaya. 2016.

12. Septian. Konsumsi Fitoestrogen, Persentase Lemak Tubuh Dan Siklus Menstruasi Pada Wanita Vegetarian. 2016.
13. Restu Amalia. Faktor-Faktor yang Mempengaruhi Tingkat Kesegaran Jasmani pada Wanita Vegetarian. Tesis. Universitas Diponegoro. 2012

14. Nunung. Hubungan Rasio Lingkar Pinggang Panggul (RLPP) Dengan Kadar Gula Darah Pada Pegawai Di Puskesmas Sakti Pidie. 2016.

15. Ernitasari. Pola Makan, Rasio Lingkar Pinggang Pinggul (RLPP) dan Tekanan Darah Di Puskesmas Mergangsa Yogyakarta. 2009.

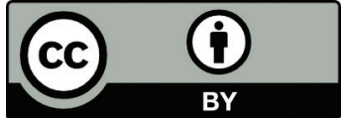

This work is licensed under a Creative Commons Attribution 